Dicle Tıp Dergisi / Dicle Med J (2019) 46 (4) : 881-883

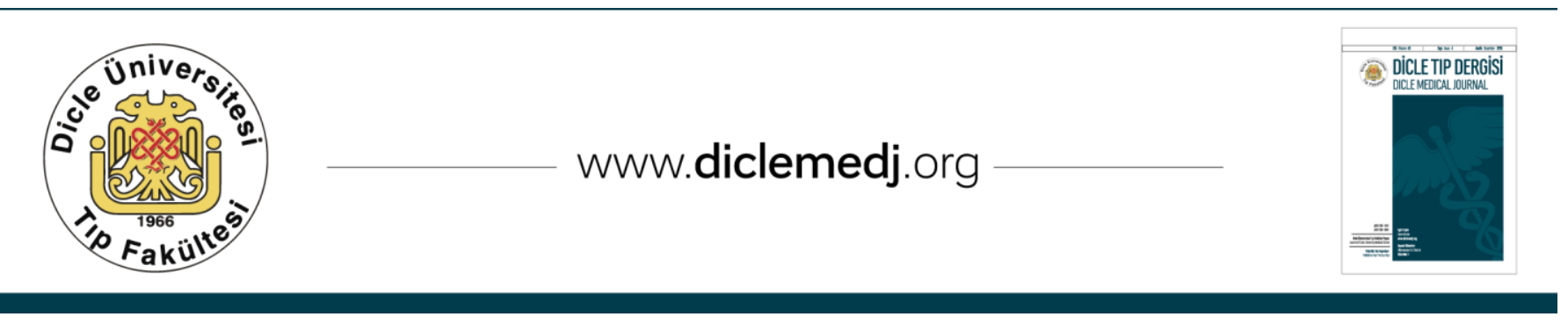

Olgu Sunumu / Case Report

\title{
A Rare Cause of Acute Abdomen in A Child: Infected Mesenteric Cyst
}

\author{
Sefa Sag1, Burcu Kemal Okatan², Nigar Metin ${ }^{3}$ \\ 1 University of Health Sciences, Kanuni Education and Research Hospital, Dept. of Pediatric Surgery, Trabzon, Turkey ORCID: 0000-0002-0904-315X \\ 2 University of Health Sciences, Kanuni Education and Research Hospital, Department of Pathology, Trabzon, Turkey 0RCID: 0000-0001-6148-5388 \\ 3 University of Health Sciences, Kanuni Education and Research Hospital, Department of Radiology, Trabzon, Turkey ORCID:0000-0001-7814-0968
}

Received: 28.05.2019; Revised: 29.07.2019; Accepted: 05.08.2019

\begin{abstract}
Mesenteric cysts are rare lesions and they are usually asymptomatic. Acute abdomen caused by infection of cyst is a very rare complication. We present a child with mesenteric cyst who presented acute abdomen and was treated with total cystectomy. Although mesenteric cysts are usually asymptomatic, they may cause serious complications. So, even if they are asymptomatic and diagnosed incidentally, these cysts should be closely monitored and surgical treatment should be considered for large cysts.
\end{abstract}

Keywords: Mesenteric cyst, infection, child, surgery

\section{Bir Çocukta Akut Abdomenin Nadir Nedeni: Enfekte Mezenterik Kist}

Öz

Mezenterik kistler nadir lezyonlardır ve genellikle asemptomatiktirler. Kist enfeksiyonunun neden olduğu akut karın, bu lezyonların çok nadir görülen bir komplikasyonudur. Biz çalışmamızda; akut karın bulgularıyla başvuran ve total kistektomi ile tedavi edilen enfekte mezenter kistli bir çocuğu sunuyoruz. Mezenterik kistler genellikle asemptomatik olmalarına rağmen ciddi komplikasyonlara neden olabilirler. Bu yüzden, asemptomatik olsalar ve tesadüfen teşhis edilmiş olsalar bile, bu kistler yakından izlenmeli ve büyük kistler için cerrahi tedavi düşünülmelidir.

Anahtar kelimeler: Mezenterik kist, enfeksiyon, çocuk, cerrahi. 


\section{INTRODUCTION}

Mesenteric cysts are benign cystic lesions. They can occur anywhere in the mesentery of the gastrointestinal tract from duodenum to rectum, and they are most commonly seen in the ileal mesentery ${ }^{1}$. These cysts are detected in all age groups but incidences of pediatric mesenteric cysts are very low ${ }^{3,4}$. Although they are usually asymptomatic, they may present with various complications. Acute abdomen caused by infection is a very rare complication of these lesions. We want to share a child with mesenteric cyst presented acute abdomen.

\section{CASE}

A five years old boy was admitted to our clinic with severe abdominal pain developed suddenly. There was no familial and medical history of any similar symptoms. At initial admission; the pulse was 103 times/minute, respiration rate was 32 times/minute and body temperature was $38.7^{\circ} \mathrm{C}$. On the physical examination; we noted abdominal tenderness, muscle rigidity in the right abdomen. Abdominal ultrasound (USG) revealed the 74 $\mathrm{x} 48 \mathrm{~mm}$ and $67 \mathrm{x} 60 \mathrm{~mm}$ sized bilobular cystic mass with dense content in right abdomen. Computer tomography (CT) was performed for differential diagnosis and revealed cystic lesions with septa formations at the right lower quadrant level with a size of $74 \times 48 \mathrm{~mm}$ and $81 \times 56 \mathrm{~mm}$ in the anterior part of the bladder (mesenteric cyst?) (Figure 1). In the laboratory analysis; white blood cell was $15.1 \mathrm{~K} / \mathrm{uL}$ (4-10 $\mathrm{K} / \mathrm{uL})$, hemoglobin was $11.5 \mathrm{~g} / \mathrm{dl}(12-17 \mathrm{~g} / \mathrm{dl})$, C-reactive protein was $12.74 \mathrm{mg} / \mathrm{dL}(0-0.5$ $\mathrm{mg} / \mathrm{dl})$, platelet was $289.000 \mathrm{~K} / \mathrm{uL}(130-400$ $\mathrm{K} / \mathrm{uL}$ ). Liver and renal function tests, electrolytes and blood gas values were normal. Surgery was planned for the patient and performed by laparotomy. Complete cyst resection without bowel resection was performed. In pathological examination; the appearance was consistent with simple mesenteric cysts containing abscesses, bleeding, and infectious reactive changes (Figure 2). There was no complication after surgery. The patient was discharged on the 3rd day after the operation and was invited to the clinic at the one and six months after postoperative period. There were not clinical symptom and radiologic findings in the patient.

Informed consent was received from the patients' parent.

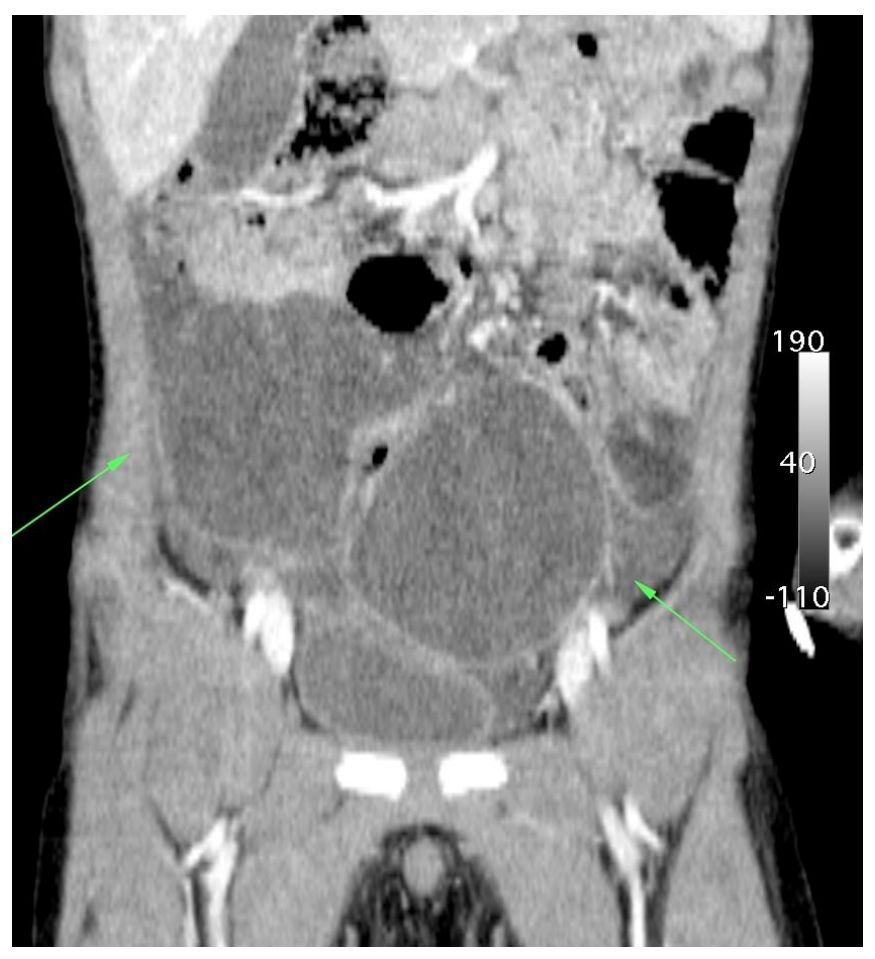

Figure 1: Computer tomography findings for mesenteric cyst. Bilobular cystic mass with dense content in ileal mesentery.

\section{DISCUSSION}

Mesenteric cysts can be classified as being of lymphatic, mesothelial, enteric, urogenital, dermoid cystic and pseudo-cystic origin histopathologically ${ }^{2}$. They are rare and benign tumors that may occur anywhere in the mesentery of the gastrointestinal tract but most commonly seen in the ileal mesentery ${ }^{1}$. In our case, the mesenteric cyst was in the ileal mesentery. 


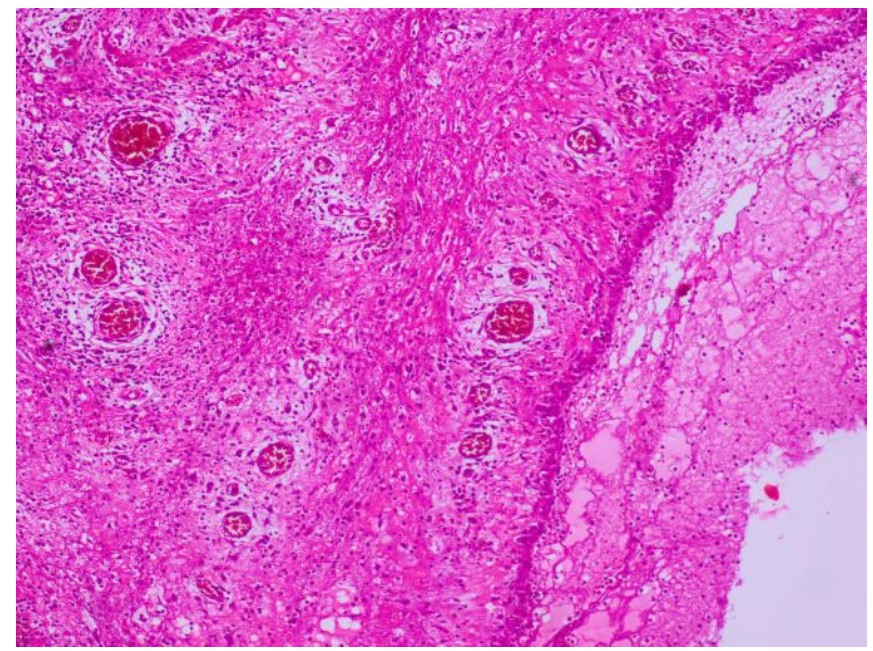

Figure 2: Pathologic findings. Mesenteric epithelial lining surrounded by active chronic inflammation, fibrosis and granulation tissue.

Although these cysts are detected in all age groups, they are most commonly seen in the 40-70 age of group 3 . Incidence of pediatric mesenteric cyst is very low ${ }^{4}$. Etiology has not been clearly discovered yet, but continued growth of congenital lymphatic tissue, failure of the leaves of the mesentery to fuse, degeneration of the lymphatics due to abdominal trauma, previous pelvic surgery, endometriosis, pelvic inflammatory disease, and neoplasia have been suggested formation of these cysts 2,5 .

Mesenteric cysts are usually asymptomatic and incidentally detected during physical or radiological examination or when a complication develops. Abdominal symptoms are usually abdominal pain, palpable abdominal lumps and abdominal distention. Patients who have complications such as infection, hemorrhage, volvulus, perforation or bowel obstruction may present with acute abdomen ${ }^{6}$. Shamiyeh et al. ${ }^{7}$ reported that mesenteric cysts larger than $5 \mathrm{~cm}$ can be symptomatic. Similarly, our case presented with acute abdominal pain caused by infection, and he had a cyst of $8 \mathrm{~cm}$ size.
Treatment of mesenteric cysts is surgery. Although simple aspiration and marsupialization are recommended, total cystectomy is accepted as the gold standard to avoid high recurrence rate and risk of infection $^{8}$. We performed complete cyst resection without bowel resection by laparotomy. There were no complications in the postoperative period and during the next 6 months.

In conclusion; mesenteric cysts are very rare lesions. They are usually asymptomatic but they may cause serious complications such as infection, perforation, hemorrhage, bowel obstruction. These cysts especially the ones larger than $5 \mathrm{~cm}$, even if they are asymptomatic and diagnosed incidentally, surgical treatment should be considered.

Declaration of Conflicting Interests: The authors declare that they have no conflict of interest.

Financial Disclosure: No financial support was received.

\section{REFERENCES}

1. Liew SC, Glenn DC, Storey DW. Mesenteric cyst. Aust N Z J Surg. 1994; 64: 741-4.

2. De Perrot M, Brundler MA, Totsch M, et al. Mesenteric cysts Toward less confusion? Dig Surg. 2000; 17: 323-8.

3. Sato M, Ishida $\mathrm{H}$, Konno $\mathrm{K}$, et al. Mesenteric cyst: sonographic findings. Abdom Imaging. 2000; 25: 30610.

4. Chung MA, Brandt ML, St-Vil D, Yazbeck S. Mesenteric cysts in children. J Pediatr Surg. 1991; 26: 1306-8.

5. Sardi A, Parikh KJ, Singer JA, Minken SL. Mesenteric cysts. Am Surg.1987; 53: 58-60.

6. Kim EJ, Lee SH, Ahn BK, Baek SU. Acute abdomen caused by an infected mesenteric cyst in the ascending colon: a case report. J Korean Soc Coloproctol. 2011; 27: 153-6.

7. Shamiyeh A, Rieger R, Schrenk P, Wayand W. Role of laparoscop-ic surgery in treatment of mesenteric cysts. Surg Endosc.1999; 13: 937-9.

8. Tan JJ, Tan KK, Chew SP. Mesenteric cysts: an institution experience over 14 years and review of literature. World J Surg. 2009; 33: 1961-5. 